Editorial

\title{
Novel coronavirus infection: time to stay ahead of the curve
}

Ala Alwan, Jaouad Mahjour ${ }^{7}$ and Ziad A. Memish ${ }^{3}$

In 2003, the World Health Organization $(\mathrm{WHO})$ steered an unprecedented global response to successfully control severe acute respiratory syndrome (SARS), a new disease caused by a previously unknown coronavirus. This became the first major international health emergency in the 21 st century [1]. Almost 10 years later in June 2012, the discovery of another novel strain of SARS-like coronavirus [2] sparked similar alarm. This virus belongs to the same family of viruses that caused SARS in 2003. It also causes unusually severe pneumonia and death in a majority of patients [3]. Because a significant proportion of cases have been acquired in our region, it has had a significant impact on the countries of the Eastern Mediterranean.

By April 2013, as the number of fatalities from the Eastern Mediterranean region rose to 9 and with 14 confirmed cases [4], the situation raised some pressing questions. This virus had not been detected in humans or animals previously [5], and although most cases were sporadic, recent evidence oflimited person-to-person transmission from index case to family members heightened concerns. The latest cluster involved a United Kingdom (UK) resident who seemed to have acquired his infection in south Asia or the Middle East. Two family members who became ill on his return were subsequently diagnosed with novel coronavirus infection. The fact that neither had travelled outside of the UK provided the first convincing evidence of person-to-person transmission [6].

The origin of this virus remains unknown. Early scientific evidence suggests that the virus might already be widespread in animals [7] but much about this virus remains to be understood. Important questions to be answered include the origins of the outbreak, how widespread it is in nature, whether it is a zoonotic infection, and how it emerged in humans as a virulent pathogen. Most important of all is whether infection can be sustained through human-to-human transmission. Its risk to global health will be fully understood once the scale and evolution of this virus is known. Geographic monitoring is a priority, particularly mapping across jurisdictions.

In January this year, experts from WHO and other international health bodies assembled in Cairo to discuss what is currently known about this virus. Efforts to answer important questions have been made as shown by Angus Nicoll, Anthony Mounts and colleagues in this issue of the EMHJ. Articles from Richard Pebody, Bassam Hijawi and others have also contributed important new data. The papers published in this issue of the Journal provide a convincing demonstration of the global health community working together to build the evidence base that will guide and inform public health decisions.
Our experience with novel coronavirus infection reinforces the benefits of regional engagement amongst WHO Member States. It also highlights the cooperation that is necessary to successfully combat international health threats within the spirit and framework of International Health Regulations (2005) [8]. WHO and international scientific communities have benefitted from the willingness of countries in our region to share viruses and information immediately. This has allowed timely sequencing studies and the rapid development of diagnostic tests.

Ten years after the world successfully contained SARS, critical questions remain. How safe is the international community? Are we prepared for another global event like SARS? There are mounting concerns over a succession of new pathogens identified since the turn of the century [9]. The world has already experienced the century's first influenza pandemic. This event was preceded by another outbreak of global importance - avian influenza caused by $\mathrm{H} 5 \mathrm{~N} 1$ virus. Lessons from avian influenza, pandemic influenza, the recent emergence of novel coronavirus infection in the Middle East and influenza $\mathrm{A}(\mathrm{H} 7 \mathrm{~N} 9)$ virus in China [10] demonstrate that all these diseases have in common "known unknowns". New pandemic diseases will emerge again in the future. Novel microbes that are sustained in nature will eventually spill over again to infect human populations. When this happens, another

${ }^{7}$ Regional Director, World Health Organization Regional Office for Eastern Mediterranean, Cairo, Egypt.

${ }^{2}$ Director, Department of Communicable Disease Prevention and Control, World Health Organization Regional Office for Eastern Mediterranean, Cairo, Egypt.

${ }^{3}$ Deputy Minister of Health for Public Health, Ministry of Health, Riyadh; Professor, College of Medicine, Al Faisal University, Riyadh, Kingdom of Saudi Arabia (Correspondence to ZiadA. Memish: zmemish@yahoo.com). 
major international health crisis will be announced [11].

The emergence two human pathogens, novel coronavirus and influenza A(H7N9) virus, within the past few months reminds us that global health is not yet safe. Although these events could not be predicted, we can still gain if we are better prepared through shared and joint defences. This will require constant vigilance, proactive surveillance and targeted response systems across all countries. Such systems should be designed to optimize disease intelligence and to improve risk forecasting. The current priority is to monitor coronavirus infections for evidence of sustained human-to-human transmission. While it is important to weigh the evolving risk on a prospective basis, we must stay ahead of the curve. Expecting the unexpected will be the cornerstone for WHO's vision of global health security. It will also be a test of the global public health community's collective response to this new infectious disease.

The global publichealth community must attempt to understand the public health risk associated with this virus. No one knows how far the disease might spread and its ultimate ramifications for the region and also the world.

\section{References}

1. Heyman DL, Mackenzie JS, Peiris M. SARS Legacy: outbreak reporting is expected and respected. Lancet, 2013, 381:779-781.

2. ProMED-mail. Novel coronavirus - Saudi Arabia: human isolate. Archive number: 20120920.1302733. 20 September 2012 (http://www.promedmail.org/?p=2400:1000, accessed 4 October, 2012).

3. Nuttall I, Dye C. The SARS wake-up call. Science, 2013, 339:1287-1288.

4. World Health Organization. Global alert and response (GAR). Novel coronavirus infection - update. 26 March 2013 [webpage]. (http://www.who.int/csr/don/2013_03_26/en/index.html, accessed 10 April, 2013).

5. Corman VM et al. Detection of a novel human coronavirus by real-time reverse-transcription polymerase chain reaction. Eurosurveillance, 2012, 17(39):pii 20285 (http://www. eurosurveillance.org/ViewArticle.aspx?Articleld=20285, accessed 2 May 2013).
6. Update: Severe respiratory illness associated with a novel coronavirus-worldwide, 2012-2013. MMWR Morbidity and Mortality Weekly Report, 2013, 62(10):194-195.

7. Müller MA et al. Human coronavirus EMC does not require the SARS-coronavirus receptor and maintains broad replicative capability in mammalian cell lines. mBio, 2012, 3e00515-12 (http://mbio.asm.org/content/3/6/e00515-12.long, accessed 2 May 2013).

8. International Health Regulations, 2005, 2nd ed. Geneva, World Health Organization, 2008.

9. Lightfoot N, Rweyemamu M, Heymann DL. Preparing for the next pandemic. BMJ (Clinical Research ed), 2013, 346:f364.

10. Uyeki TM, Cox JN. Global concerns regarding novel influenza A (H7N9) virus infection. New England Journal of Medicine, 2013, Dol: 10.1056/NEJMp1304661 (http://www.nejm.org/ doi/full/10.1056/NEJMp1304661, accessed 2 May 2013).

11. Morse SS et al. Prediction and prevention of the next pandemic zoonosis. Lancet, 2012, 380:1956-1965. 